\title{
NATURE OF VICTIMIZATION AND DEVIANT BeHAVIOR AMONG Homeless Adolescents: A STUDY IN GAZIPUR
}

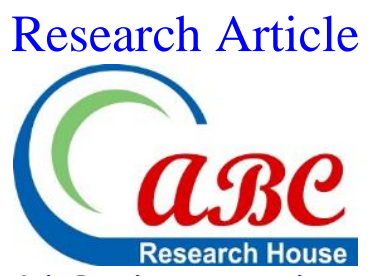

Asia Pac. j. energy environ.

\section{Mohammad Ashraful Alam ${ }^{1}$, Mahmuda Akter ${ }^{2}$}

\author{
${ }^{1}$ Associate Professor, Department of Criminology and Police Science, Mawlana Bhashani Science and Technology University, Santosh, \\ Tangail-1902, BANGLADESH \\ ${ }^{2}$ MS Student, Department of Criminology and Police Science, Mawlana Bhashani Science and Technology University, Santosh, \\ Tangail-1902, BANGLADESH
}

*Email for Correspondence: prodip_sust2005@yahoo.com

Abstract

Homeless adolescents are at great risk for both victimization and perpetration. The key objectives of the study is to know the nature and causes of victimization and deviant behavior among homeless adolescents in Bangladesh, identify the pattern of victimization particularly in employment sector and in social life and the issues that encourage the homeless adolescents to be involved in deviant behavior. This study is based on descriptive research which found significant information on socio-demographic characteristics of homeless adolescents, involvement in work for earning livelihood at early age, scenery of victimization in working environment, and finally participating in deviant behavior. Homeless adolescents become socially victimized as in most of cases, they have no regular contact with their family, and many adolescent even did not complete their primary education, deprived from basic rights of medical, sports and recreational facility. Furthermore, maximum homeless adolescents are day laborers and are involved in risky employment for long time, getting negligible salary and majority of them are become victim of physical torture and sexual harassment. Besides, most of the homeless adolescents get very harsh behavior from public and large numbers of them are arrested by the police during working. Thus, underprivileged homeless adolescents are become precariously victimized in society. Consequently, most of homeless adolescents are involved in pity offences, became drug abuser and gradually involved with various criminal gangs. So the study finally finds that homeless adolescent are being victimized in different perspective and also being involved with delinquency and serious crimes.

Key words

Homeless Adolescents, Livelihood and Working condition, Victimization, Deviant Behavior

This article is is licensed under a Creative Commons Attribution-NonCommercial 4.0 International License.

Attribution-NonCommercial (CC BY-NC) license lets others remix, tweak, and build upon work non-commercially, and although the new works must also

acknowledge \& be non-commercial.

\section{INTRODUCTION}

Homeless adolescents have traditionally been victimized at greater rates than other adolescents in society. Homeless adolescents are at special risk for both victimization and perpetration. Many adolescent become occupied in survival tactic to ensure basic requirements and security of living without vulnerability. Sometimes, criminality may perhaps affiliate with deviant peers on the street (Whitbeck \& Simons, 1990). Adolescents vacillate between being children and being adults not having reached maturity. According to UNICEF (2010), adolescence is also equated to both the terms "teenage years" and "puberty." Puberty refers to the hormonal transformation of an adolescent in the early youth stage which phase may enlarge well further than the young days. The World Health Organization (WHO) defines adolescence as the period of life between ages 10 and 19 years. They are regulating to the physiologic changes their bodies that are undergoing and trying to launch a sexual identification to use these transformations for their personal benefit in want of self-determination and freedom of thought (Endres, 2010). According to UNICEF (2010), there are 27.7 million adolescents aged between 10-19 years in Bangladesh where 13.7 million girls and 14 million boys making up about one fifth of the total population (of which $75 \%$ are in Dhaka city). In reaction to many social problems, homeless adolescents have a tendency to capitulating peer demands and conform to group ethics, behaviors and experiences in as clothing, food and entertainment. Homeless adolescents are exposed to such environments that demands caring reactions or survival policies which increased the necessity of self protection, involved violence as the way to an end. 
The United Nations Convention on the Rights of the Child (UNCRC) generally defines a child as any human being below the age of eighteen years, unless an earlier age of majority is accepted by the country's law (UNICEF, 2010). It is a human rights treaty setting out the civil, political, economic, social, and cultural rights of children. Dysfunctional childhood includes disruptions of families of origin, parental problem behavior and physical as well as sexual abuse generates patterns of learned helplessness, disaffiliation and cycles of abuse of that results homelessness (Kipke \& colleagues, 1997). Victimization as a consequence of homelessness is a condition so fraught with peril that homeless adults experience. Almost 65\% homeless adolescents are deprived from nutrition (save the children, 2009). 149000 are involved in dangerous working, 10 lack are domestic worker of Dhaka city (ILO, 2009), 67400 have become street children (BIDS, 2005), 13220 homeless adolescents especially female are become sexual victim and per year 2 lack are trafficked (Odhikar, 2011). So, the homeless adolescents are seriously victimized in our society.

In addition, poverty accompanied by stigma and social discrimination endure a loss of safe housing, proper health care, uninterrupted schooling, sustaining relationships and a sense of community continuity which hindered their education $(\mathrm{NCH}, 2009)$. Homelessness condition of children are directly related to the spectacular and alarming increases high rates of suspensions, school turnover, expulsions and often improperly assigned in special education assignment. Because of many social problems, the homeless adolescents are choosing different ways of living like staying away from home, parents and relatives, getting involved in hard and dangerous labor work with adult people. According to Article 32 of Children Act, 1974 the government must take measure for the care and protection of destitute and neglected as well homeless children. Moreover, in many articles of UNCRC basic rights of adolescent must be ensured. But in practice there is not many efficient programs are not run by Bangladesh government. The criminal justice systems of Bangladesh do not take proper measures to protect homeless adolescents

Homeless young are exposed to such environments that may insist defensive reactions or endurance approaches that increased the need for self protection. Violence begets violence in a cycle of victimizing behaviors and victimization process (Baron \& Hartnagel, 1998). With this process, at early childhood, those become unable to deal with demands of adult life, becoming and left behind homeless. The most important criteria are to recognize that adolescents are no longer children (Tyler, Kimberly, Beal \& Morgan, 2010). Their 'too early' adult behaviors have prepared their intelligent adults that resisted any effort to demoralize their condition. Over and over again, homeless adolescents do not search for remedy from the law enforcement system, observed that police are less responsive to the needs of the homeless than the general population. Consequently, their more serious or violent crimes are more likely to be reported in the media. Another reason that, homeless adolescents fail to report crimes because the police may behave as opponent rather than champions and reports of police harassment are common. Besides, health care and other human services systems acquired through victimization of homeless people need to take under consider. Moreover, it is also important to judge the ways that violent behaviors may become responsible for both the psychological and physical harm of homelessness adolescents.

\section{ObJectives}

The key objective of this study is to explain the nature of victimization and deviant behavior among homeless adolescents in Gazipur. The additional objectives of this study are:

- To recognize the causes of victimization among the homeless adolescents;

- To identify their victimization types particularly in employment sector and social life of homeless adolescents;

- To find out the issues that promote the homeless adolescents to involved in deviant behavior.

\section{METHODOLOGY OF THE STUDY}

This study is quantitative in nature and Survey research method was used for data collection. Simultaneously, some case study was taken through a semi structured questionnaire to justify the collected information from the field and to make additional support for the in-depth analysis of the problem. Gazipur is the nearest city of the capital Dhaka city and is the largest city corporation of Bangladesh. This city is divided into industrial, residential and commercial areas where many people live temporarily to maintain their livelihood. Gradually the numbers of homeless adolescent is increasing because of growing the importance of the city as industrial zone. Other way Gazipur city has some other characteristics like- its size, density of population, peripheral location in relation to capital city that lead to the availability of information of data. Regarding the above mentioned issues, Ershadnagar (Bastuhara) area and Station road area of Tongi thana under Gazipur city was selected purposively for the availability of homeless adolescent. This study is based on descriptive research where the non probability accidental sampling method was used to conduct the survey. As there is no fixed official statistic about homeless adolescent of Gazipur, the accidental sampling method was used to conduct the survey and primarily 120 homeless adolescents was interviewed as a sample with mixed and structured questionnaire through directed face to face interaction for collecting the desire information. Here the case study method was used to examine the current phenomenon of homeless adolescents' victimization and to address the problem of committing delinquent behavior. The data were processed and analyzed by using various statistical tools like-descriptive and inferential statistics. 


\section{RESULTS AND Discussion}

Homeless adolescents are staying away from home and parental care. According to this study, they are deprived from their basic needs such as schooling, proper health care and become involved in dangerous hard labor work with adult. Besides, they endure a loss of safety, sustaining relationships. As a result, various physical and sexual harassment builds low sense of community and stability that negatively impact in their socialization. Nobody guide them, monitoring them and take care of them. Consequently, homeless adolescents become victim in every steps of life which encourages them to do many delinquent behaviors in society.

\section{Socio Demographic characteristics of homeless adolescents}

According to Table 1 of this study, among 120 homeless adolescents, maximum (53.3\%) belongs to the age 13-15 years, and almost $35 \%$ are belongs to the age of 16-19 years. This study also shows that in most cases male adolescents $(78.3 \%)$ become homeless than female (21.7\%). That means male adolescents become more homeless are than the female adolescents.

Adolescent's future depends on their parents. Lack of parental relationship effects on deviant or criminal activities because of children's socialization depend on their parents. From Table 1, in maximum cases, homeless adolescents respondent' father mother has dead (47.5\%) while only 13.3\% homeless adolescents father and mother are alive, $29.2 \%$ respondent's father are alive and 10\% respondent's mother are alive. According to a report published by the government news agency Bangladesh Shongbad Shongsta (2002), there were approximately 40 thousand homeless adolescent of which 15 thousand had no information of their parents. So, it can be said that those adolescents are much homeless whose parents has dead than the others.

The living environment plays a vital role in the process of appropriate socialization of people. Table 1 show that maximum homeless adolescents sleep in slum (44.2\%) at night. In addition, many homeless adolescents sleeps in rail station $(20.2 \%)$, Bus station $(11.7 \%)$, Roads $(15.0 \%)$ and in other places $(9.2 \%)$. For these reason, the chances of being victimized of them in narrow social life are increased. Besides, according to this study, most homeless adolescents never meet with their family $(70 \%)$. Only few homeless adolescents meet with their family after 7 days $(1.6 \%)$, after 15 days $(8.3 \%)$, and after 1 month $(19.1 \%)$. Consequently, maximum homeless adolescents have no regular contract with their family which creates poor familial and social bond. As a result, a chance of their deviant behavior is generated.

Table 1: Socio Demographic characteristics of respondents

\begin{tabular}{|c|c|c|c|}
\hline & & Number & Percent (\%) \\
\hline \multirow{3}{*}{ Age group } & $10-12$ & 14 & $11.7 \%$ \\
\hline & $13-15$ & 64 & $53.3 \%$ \\
\hline & $16-19$ & 42 & $35.0 \%$ \\
\hline & Total & 120 & $100.0 \%$ \\
\hline \multirow[t]{2}{*}{ Sex } & Male & 94 & $78.3 \%$ \\
\hline & Female & 26 & $21.7 \%$ \\
\hline \multicolumn{2}{|r|}{ Total } & 120 & $100.0 \%$ \\
\hline \multirow{4}{*}{ Status of parents } & Both alive & 16 & $13.3 \%$ \\
\hline & Both dead & 57 & $47.5 \%$ \\
\hline & Only father alive & 35 & $29.1 \%$ \\
\hline & Only mother alive & 12 & $10.0 \%$ \\
\hline & Total & 120 & $100.0 \%$ \\
\hline \multirow{5}{*}{ Place of sleeping at night } & Slum & 53 & $44.2 \%$ \\
\hline & Rail station & 24 & $20.0 \%$ \\
\hline & Bus station & 14 & $11.7 \%$ \\
\hline & Road & 18 & $15.0 \%$ \\
\hline & others & 11 & $9.2 \%$ \\
\hline & Total & 120 & $100.0 \%$ \\
\hline \multirow{5}{*}{ Contact with family } & After 7 days & 2 & $1.6 \%$ \\
\hline & After 15 days & 10 & $8.3 \%$ \\
\hline & After 1 months & 1 & $.83 \%$ \\
\hline & More than 1 months & 23 & $19.1 \%$ \\
\hline & Never & 84 & $70.0 \%$ \\
\hline \multicolumn{2}{|r|}{ Total } & 120 & $100.0 \%$ \\
\hline
\end{tabular}




\section{Nature of victimization of Homeless adolescents}

\section{Deprivation from basic needs}

Education is the route of knowledge in which to acquire knowledge by training, studies and others way. According to article 28 of UNCRC ensure about the right of education. Table 2 shows that most of the homeless adolescents do not get the facility of education. From this research we found that among the total of homeless adolescent's respondent. Majority of homeless adolescents do not continue their studies. They are deprived from their basic rights of receiving education where in the. As the educational facility is very poor, their psychological and socialization process failed to develope properly.

According to the article 25 of UNCRC, medical facilities of adolescent should ensured by the government. From Table 2 we found that, among total respondents only $4.2 \%$ get opportunity of medical facilities while $95.8 \%$ homeless adolescents have not the opportunity of medical facilities. Street dwellers in the city are extremely vulnerable in terms of their health needs, hygiene scope, and utilization of healthcare services and become marginalized by public and private sectors. A hygiene study by Institute of Cholera and Diarrhoeal Diseases Research, Bangladesh (ICDDR.B) found that most street dwellers have been suffering from the diseases of respiratory and digestive system weakness, severe pain and scabies.

Article 27 of UNCRC gives importance in ensuring the adequate recreational facilities of adolescent. From this research we noticed that, among total respondents. Only $45.8 \%$ get opportunity of sports while $54.2 \%$ homeless adolescents do not get opportunity of Sports. As they work for a long time, they do not get proper facility of sports. Table 2 also shows that, only $40.8 \%$ get opportunity of recreation while $59.2 \%$ homeless adolescents have no opportunity of recreation. Thus they are deprived from their basic recreational facilities.

Table 2: Deprivation from basic needs of respondents

\begin{tabular}{|l|c|c|c|c|c|c|c|c|}
\hline \multicolumn{2}{|l|}{ Educational Facility } & \multicolumn{2}{c|}{ Medical facility } & \multicolumn{2}{c|}{ Sports facility } & \multicolumn{2}{c|}{ Recreational facility } \\
\hline & Number & $(\%)$ & Number & $(\%)$ & Number & $(\%)$ & Number & $(\%)$ \\
\hline Having & 16 & 13.3 & 5 & 4.2 & 55 & 45.8 & 49 & 40.8 \\
\hline Not Having & 104 & 86.7 & 115 & 95.8 & 65 & 54.2 & 71 & 59.2 \\
\hline Total & $\mathbf{1 2 0}$ & $\mathbf{1 0 0 . 0}$ & $\mathbf{1 2 0}$ & $\mathbf{1 0 0 . 0}$ & $\mathbf{1 2 0}$ & $\mathbf{1 0 0 . 0}$ & $\mathbf{1 2 0}$ & $\mathbf{1 0 0 . 0}$ \\
\hline
\end{tabular}

\section{Victimization in working environment}

For earning livelihood, homeless adolescent become engaged in employment from the early age. There are no fixed way of employment for homeless adolescent, the involved in employment according to their own preference. According to Table 3, maximum 88.3 percent are involved in the employment. From this survey, we found that maximum homeless adolescent's are day laborers $(68.3 \%)$ while few respondents are domestic worker $(17.5 \%)$ and involved in begging (14.2\%). Getting involved in the work of day laborer, homeless adolescent are doing different work in a hazardous occupations and sectors like bidi (hand-rolled cigarette) factories, building, leather tanneries, fisheries, automobile repair, welding, bangle-making, rickshaw-pulling, matches manufacturing, brick-breaking, book binding, and the garment industry, selling newspaper/pop-corn/tea/flower/pickle/spicy-puff, and as tempo helper etc. But who work as domestic worker are safer than day laborer.

According to Table 3, maximum of the homeless adolescents are working 4-8 hours per day (75\%) while few of them are working above $1-4$ hours $(19.2 \%)$ and only $5.8 \%$ are working more than 8 hours in a day. The struggling life of homeless adolescent becomes more difficult when they are busy in earning by working for a long time of hard work in everyday. The International Labor Organization (2007) found that 149,000 homeless adolescents in employment sectors worked an average of nine hours a day. The majority of those questioned said they worked six or seven days a week for little or no wages.

From this study, Table 3 shows that, the maximum salary of homeless adolescents is less than 100 taka (79.2\%). But in few of them get 100 taka (10\%) and 100-150 taka (5.8\%) and homeless adolescents get more than 150 taka $(4.5 \%)$ as a salary per day. Thus, homeless adolescents are providing small amount of salary which makes them bound to involve with pity offence. According to the BBS and International Labor Organization survey, homeless adolescents earned an average monthly wage of just 288 taka (\$US4.85) by collecting old paper, street selling, shining shoes, pottering or begging etc. while those in the transport sector received an average of 1,417 taka (\$US24) a month.

According to Table 3, in most of the cases, homeless adolescents are not getting the salary in due time (95\%) while only few of them getting salary in time (5\%). After doing risky work for a lengthy period they are struggling to get the salary in time. Thus, from the privileged class of the society they are victimized in their working sector 
Table 3: Victimization in working environment of respondents

\begin{tabular}{|c|c|c|c|}
\hline \multirow{2}{*}{ Types of employment } & Domestic worker & Number & Percent (\%) \\
\cline { 2 - 4 } & Day labor & 82 & $17.5(\%)$ \\
\cline { 2 - 4 } & Begging & 17 & $68.3(\%)$ \\
\hline \multirow{2}{*}{ Total } & & 120 & $100.0(\%)$ \\
\hline \multirow{2}{*}{ Working duration } & $1-4$ hours & 23 & $19.2(\%)$ \\
\cline { 2 - 4 } & $4-8$ hours & 90 & $75.0(\%)$ \\
\cline { 2 - 4 } & More than 8 hours & 7 & $5.8(\%)$ \\
\hline \multirow{2}{*}{ Total } & & 120 & $100.0(\%)$ \\
\hline \multirow{2}{*}{ Income per day } & Less than 100 taka & 95 & $79.2(\%)$ \\
\cline { 2 - 4 } & 100 taka & 13 & $10.8(\%)$ \\
\cline { 2 - 4 } & $100-150$ taka & 7 & $5.8(\%)$ \\
\cline { 2 - 4 } & More than 150 taka & 5 & $4.5(\%)$ \\
\hline \multirow{2}{*}{ Total } & & 120 & $100.0(\%)$ \\
\hline Getting salary in due time & Yes & 6 & $5(\%)$ \\
\cline { 2 - 4 } & No & 114 & $95(\%)$ \\
\hline \multirow{2}{*}{ Total } & & 120 & $100.0(\%)$ \\
\hline
\end{tabular}

\section{Victim of Physical assault and sexual harassment}

According to the article 19 of UNCRC, nobody should practice any physical assault against adolescent. But from Table $4,72.5 \%$ of the homeless adolescents are victim by physical torture while only $27.5 \%$ of homeless adolescents are not facing any physical assault. Moreover, this study shows that $55.8 \%$ of the respondents are victim dangerous physical torture while only $44.2 \%$ of homeless adolescents are facing simple physical assault.

Sexual harassment occurs when employment benefits are made contingent on sexual favors or when touching, coarse comments or presentation of pornography objects creates a hostile environment in the work place. According to the article 34 of UNCRC, nobody should practice any sexual assault against adolescent which should guaranteed by the government. Table 4 examined that, $24.2 \%$ of homeless adolescents are victim of sexual harassment while only $75.8 \%$ are not facing any sexual harassment.

Table 4: Victim of Physical assault and sexual harassment

\begin{tabular}{|c|c|c|c|c|}
\hline \multicolumn{2}{|c|}{ Victim of physical assault } & \multicolumn{2}{c|}{ Victim of sexual assault } \\
\hline & Number & $(\%)$ & Number & $(\%)$ \\
\hline Yes & 87 & 72.5 & 29 & 24.2 \\
\hline No & 33 & 27.5 & 91 & 75.8 \\
\hline Total & $\mathbf{1 2 0}$ & $\mathbf{1 0 0 ( \% )}$ & $\mathbf{1 2 0}$ & $\mathbf{1 0 0 ( \% )}$ \\
\hline
\end{tabular}

\section{Attitude of public and police towards homeless adolescents}

Article 39 of UNCRC says about the restriction regarding neglect, repression, torture etc against adolescent. From Table 5, 6.7\% of the homeless adolescents get moderate behave from the public, $5 \%$ get good behavior, and $19.2 \%$ get bad and $69.2 \%$ get very bad behavior from public. Attitude of public towards homeless adolescent are rough. They become labeled as negative character for their social condition; maximum people are not interested to conduct good behavior with them. The homeless are not likely to report victimization or offending to the police for several reasons.

When police approach is experienced by homeless people as offensive, this can create distrust and discourage reporting victimization issue. From Table 5 of this study, 6.7\% of homeless adolescents get moderate behave from the police, $4.2 \%$ get good behavior and $23.3 \%$ get bad and $65.8 \%$ get very bad behavior from police. In this way, they become victimized by negative attitude of criminal justice agency.

According to the article 32 of UNCRC, it is the duty of law enforcement agency of the country to provide proper legal response towards adolescent. It is observed from the study that, maximum homeless adolescents were arrested by the police during working while only few of them are not arrested by the police. Some homeless people have criminal records and avoided reporting victimization as they do not draw unnecessary police attention. Homeless youth are especially reluctant and fears that the police will mistrust them, or they may commit an illegal act at the time of the discrimination, and finally decide not to report to police as a means of protecting themselves. 
Table 5: Attitude Public and police towards respondents

\begin{tabular}{|c|c|c|c|c|}
\hline \multicolumn{3}{|c|}{ Public Attitude } & \multicolumn{2}{c|}{ Attitude of police } \\
\hline & Number & $(\%)$ & Number & $(\%)$ \\
\hline Moderate & 8 & 6.7 & 8 & 6.7 \\
\hline Good & 6 & 5.0 & 5 & 4.2 \\
\hline Bad & 23 & 19.2 & 28 & 23.3 \\
\hline Very Bad & 83 & 69.2 & 79 & 65.8 \\
\hline Total & $\mathbf{1 2 0}$ & $\mathbf{1 0 0}(\%)$ & $\mathbf{1 2 0}$ & $\mathbf{1 0 0}(\%)$ \\
\hline
\end{tabular}

\section{Types of deviant behavior of homeless adolescents}

In case of committing pity offences (minor antisocial behavior committed by adolescent which include minor theft, picketing, etc.), Table 6 shows that maximum (80\%) homeless adolescent's respondents committed pity offences and only few of them $(20 \%)$ are not committed any pity offences. Being deprived from education and proper care those homeless adolescents lose their sense of right and wrong. Peer influences also play a big role in leading them astray. Growing number of street children pose a threat to the society. This research also finds, $57.5 \%$ homeless adolescents involved in doing pity offence for social neglect, $25 \%$ for poverty, $11.7 \%$ for psychological complexity family breakdown, and $5.8 \%$ for other reasons. Consequently, they are more victimized group of society, they committing pity offences in a high number. Teenager criminals are feared to be more desperate. Due to the characteristics of young age, they do not hesitate to commit offenses without the slightest consideration of their own safety.

Drug abuse means using of drugs without any legal medical purposes and creating any physical or psychological dependence of drugs in the body. Illegal drug related business is the ordinary source of drug abuse. According to article 33 of UNCRC, adolescent must not be involved in drug abuse or drug related business. But from Table 6 we found that, $74.2 \%$ homeless adolescents are drug abuser while only $25.8 \%$ are not involving in this drug abusing. Many homeless persons are involved in purchasing and selling drugs, although they are not likely to be major drug traffickers (Finkelhor \& Asdigian, 1996).

In case of involving with criminal gang, Table 6 shows that almost the 85.8 percent homeless adolescents are not involved with criminal gang while 14.2 percent homeless adolescents are involved with various criminal gangs in the industrial city. In different ways, they are directly or indirectly involved with criminal gang and frequently commit deviant behavior. Some studies suggest that homeless people may infrequently commit minor crimes in order to get shelter or temporary place of safety, especially during the winter months as a technique to escape the cold (Elliot, Huizinga, \& Menard, 1989). Several risk factors are associated with involvement in criminal offending with the length of time individuals become homeless and their spotlight to criminal activity, peer stress, as well as substance abuse and psychological illness.

Table 6: Types of deviant behavior

\begin{tabular}{|c|c|c|c|c|c|c|}
\hline \multicolumn{3}{|c|}{ Drug Abuse } & \multicolumn{2}{c|}{ Committed pity offences } & \multicolumn{2}{c|}{ Involvement with any criminal gang } \\
\hline & Number & $(\%)$ & Number & $(\%)$ & Number & $(\%)$ \\
\hline Yes & 89 & 72.4 & 96 & 80.0 & 17 & 14.2 \\
\hline No & 31 & 25.8 & 24 & 20.0 & 103 & 85.8 \\
\hline Total & $\mathbf{1 2 0}$ & $\mathbf{1 0 0}(\%)$ & $\mathbf{1 2 0}$ & $\mathbf{1 0 0}(\%)$ & $\mathbf{1 2 0}$ & $\mathbf{1 0 0}(\%)$ \\
\hline
\end{tabular}

\section{Comparative Analysis}

According to comparative table 1, among 94 male adolescents, 21\% male homeless adolescent are domestic worker, $66 \%$ are Day labor and 12\% are engages in begging. Besides, among 26 female homeless adolescent, $4 \%$ are domestic worker, $76.9 \%$ are Day labor and $19.2 \%$ are beggar. So, male adolescent homeless worker are highly involve as day labor while female homeless adolescent are more engage in domestic work.

Cross Table no: 1 Sex of Respondent * Type of employment

\begin{tabular}{|c|c|c|c|c|c|c|c|c|}
\hline \multirow{2}{*}{$\begin{array}{c}\text { Sex of } \\
\text { Respondent }\end{array}$} & \multicolumn{9}{|c|}{ Type of employment } & \multicolumn{2}{c|}{ Total } \\
\cline { 2 - 10 } & Domestic Worker & \multicolumn{2}{|c|}{ Day Labor } & \multicolumn{2}{c|}{ Begging } & \multicolumn{2}{c|}{} \\
\cline { 2 - 10 } & Number & $\%$ & Number & $\%$ & Number & $\%$ & Number & $\%$ \\
\hline Male & 20 & $21.3 \%$ & 62 & $66.0 \%$ & 12 & $12.8 \%$ & 94 & $100 \%$ \\
\hline Female & 1 & $3.8 \%$ & 20 & $76.9 \%$ & 5 & $19.2 \%$ & 26 & $100 \%$ \\
\hline Total & $\mathbf{2 1}$ & $\mathbf{1 7 . 5} \%$ & $\mathbf{8 2}$ & $\mathbf{6 8 . 3} \%$ & $\mathbf{1 7}$ & $\mathbf{1 4 . 2} \%$ & $\mathbf{1 2 0}$ & $\mathbf{1 0 0} \%$ \\
\hline
\end{tabular}


From cross table 2, among 23 homeless adolescent, 4\% earns 100 Taka while 8\% earns 100-150 Taka and 150+ Taka and $78 \%$ earns less than 100 Taka from 1-4 hours of working. Besides, among 90 homeless adolescent, $13 \%$ earns 100 Taka while 5\% earns 100-150 Taka and 2\% earns 150+ Taka and 77\% earns less than 100 Taka from 4-8 hours of working. Moreover, 7 homeless adolescent earns less than 100 Taka from 8+ hours of working. Thus although adolescent worker works hard, they do not get the proper salary and victimized in earning their livelihood. Consequently, they become involved with mane deviant activity.

Cross Table 2- Hours of Employment * Income per Day

\begin{tabular}{|c|c|c|c|c|c|c|c|c|c|c|}
\hline \multirow{2}{*}{$\begin{array}{c}\text { Hours of } \\
\text { Employment }\end{array}$} & \multicolumn{9}{|c|}{ Income per Day (Taka) } & \multicolumn{2}{c|}{ Total } \\
\cline { 2 - 13 } & $\mathbf{1 0 0}$ & & $\mathbf{1 0 0 - 1 5 0}$ & & $\mathbf{1 5 0 +}$ & & Less than $\mathbf{1 0 0}$ & & \multicolumn{2}{c|}{} \\
\cline { 2 - 13 } & Number & $\%$ & Number & $\%$ & Number & $\%$ & Number & $\%$ & Number & $\%$ \\
\hline $\mathbf{1 - 4}$ hours & 1 & $4.3 \%$ & 2 & $8.7 \%$ & 2 & $8.7 \%$ & 18 & $78.3 \%$ & 23 & $100 \%$ \\
\hline 4-8 hours & 12 & $13.3 \%$ & 5 & $5.6 \%$ & 2 & $2.2 \%$ & 70 & $77.8 \%$ & 90 & $100 \%$ \\
\hline $\mathbf{8 +}$ hours & 0 & $0.0 \%$ & 0 & $0.0 \%$ & 0 & $0.0 \%$ & 7 & $100.0 \%$ & 7 & $100 \%$ \\
\hline Total & $\mathbf{1 3}$ & $\mathbf{1 0 . 8} \%$ & $\mathbf{7}$ & $\mathbf{5 . 8} \%$ & $\mathbf{4}$ & $\mathbf{3 . 3} \%$ & $\mathbf{9 5}$ & $\mathbf{7 9 . 2} \%$ & $\mathbf{1 2 0}$ & $\mathbf{1 0 0} \%$ \\
\hline
\end{tabular}

According to cross table 3, among 53 homeless adolescents, 81\% become victim of simple physical assault and committed pity offences while $19 \%$ are become victim of simple physical assault but not committed pity offences. Besides, among 67 homeless adolescents, 79\% become victim of serious physical assault and committed pity offences while $20 \%$ are become victim of simple physical assault but not committed pity offences. So, those adolescent become physically victimized committed pity offences and deviant behavior in the society.

Cross Table 3- Types of Physical Assault * Pity offence committed

\begin{tabular}{|c|c|c|c|c|c|c|}
\hline \multirow{2}{*}{ Types of Physical Assault } & \multicolumn{3}{|c|}{ Pity offence committed } & \multicolumn{2}{c|}{ Total } \\
\cline { 2 - 7 } & \multicolumn{2}{|c|}{ Yes } & \multicolumn{2}{c|}{ No } & \multicolumn{2}{c|}{} \\
\cline { 2 - 7 } & Number & $\%$ & Number & $\%$ & Number & $\%$ \\
\hline Simple & 43 & $81.1 \%$ & 10 & $18.9 \%$ & 53 & $100.0 \%$ \\
\hline Dangerous & 53 & $79.1 \%$ & 14 & $20.9 \%$ & 67 & $100.0 \%$ \\
\hline Total & 96 & $80.0 \%$ & 24 & $20.0 \%$ & 120 & $100.0 \%$ \\
\hline
\end{tabular}

\section{Hypothesis Test}

Hypothesis 1:

Null Hypothesis: Drug abused homeless adolescents become engage with the criminal gang. Alternative Hypothesis: Drug abused homeless adolescents do not engage with the criminal gang.

Hypothesis Test Table 1: Calculated value

\begin{tabular}{|c|c|c|c|c|}
\hline$\chi^{2}$ Test & Calculated Value & df & Significance level & Table value \\
\hline Pearson Chi-Square & 2.04 & 1 & 0.05 & 3.84 \\
\hline
\end{tabular}

From Chi-Square table-1, at 5\% significance level and 1 degree of freedom the tabulated value of chi-square is 3.84 . But calculated value is 2.04 . Here calculated value is lower than the table value with $5 \%$ level of significance in 1 degree of freedom. According to the condition of hypothesis test the null hypothesis is accepted and the alternative hypothesis is rejected. In this situation, it is mean that drug abused homeless adolescents become engage with the criminal gang of society.

\section{Hypothesis 2:}

Null Hypothesis: Public attitude encourages committing pity offences of homeless adolescents.

Alternative Hypothesis: Public attitude do not encourages committing pity offences of homeless adolescents.

Hypothesis Test Table 2: Calculated value

\begin{tabular}{|c|c|c|c|c|}
\hline$\chi^{2}$ Test & Calculated Value & df & Significance level & Table value \\
\hline Pearson Chi-Square & 5.06 & 9 & 0.05 & 16.4 \\
\hline
\end{tabular}

From Chi-Square table-2, at 5\% significance level and 9 degree of freedom the tabulated value of chi-square is 16.4 . But calculated value is 5.06. Here calculated value is lower than the table value with $5 \%$ level of significance in 9 degree of freedom. According to the condition of hypothesis test the null hypothesis is accepted and the alternative hypothesis is rejected. In this situation, it is mean that public attitude encourages committing pity offences of homeless adolescents of society. 


\section{Case Study}

Case Study: 1

Aminul Islam, 16years homeless adolescent, living in slum areas of earshadnagar with his friends. His parents are alive and living in another area of tongi. Both of his parents are illiterate. His father is a day laborer who works in the building construction side and his mother is a domestic worker. He has two brothers and five sisters. Aminul become homeless for the social and psychological problem and remaining away from home. He does not like to stay with family as there is extreme poverty and familial conflict. In fact, he meets with his parents after one month. Aminul does not take the chance of going to school. Now he is involved in selling the daily newspaper in the railway and highway and earning more than 150 taka per day. He faces many psychical assaults during selling the newspaper by the public. He does not get enough time to play games but sometimes enjoys the movie in the cinema hall. Sometimes he takes drugs with his peer groups. Most importantly, he is involved with the drug dealing of tongi area in selling and trafficking among the other area. He is doing with this anti social behavior for earning money and getting mental satisfaction by taking drugs.

\section{Case Study: 2}

Rahima Khatun, 14 years of age lived in the slum areas of Station road, Tongi. Her parent is not alive. She has two sisters and two brothers although she had no contact with them. She become homeless for social neglect. She has no educational facilities. She earns her livelihood by selling the various kinds of fresh flowers in the highways. She earns 50-70 taka per day and faces various physical assaults during selling flower. She thought that her profession is very dangerous as there are chances of road accident in the highways. Moreover, she becomes the victim of sexual harassment by public. She has few times to play with her friends. Her recreational means is watching TV in the shops of the market .Besides; Rahima committed pity theft while living in slums. She does not think that police are their friend and hates her present life. Her dream is setting a good business of flower in the future life.

\section{Case Study: 3}

Jamal Ahmed, 16 years of age, lived in Bastuhara area of Tongi. His mother is dead but father is alive, having four brothers and one sister. His father is a day laborer and married second time after her mother dead. He meets his family more than one month later and does not like to stay with his family as there is much anarchy with his stepmother. He always feels psychological complexity for his family and social problem. Thus, Jamal become homeless for social and psychological complexity. Because of poverty he never goes to school. For earning livelihood, he works as a helper in the bus (collecting ticket/money). In maximum time he sleeps in the bus station at night. Per day he earns 100-150taka but faces some serious physical assault by the bus driver. The attitude of public is not good towards him. He does not have enough medical treatment facilities in diseases. He is strongly addicted towards smoking. Police also neglect them and even he was arrested by police twice. Jamal hates his present life and want to be the owner of bus business.

\section{Case Study: 4}

Rina akter, 13 years girl lived in the slum areas the of Station road of Tongi. Both of her parents are alive. Her father is day labor and mother is domestic worker. She has four sisters and three brothers. She becomes homeless for extreme poverty and social neglect. Rina went to school in her childhood but failed to continue now. She earns her livelihood by working in the hotel and faces physical assault for any pity mistakes. Attitude of general public is not good towards her. She does not have proper sports, medical facility but only few minutes of watching TV. Even sometimes she committed theft money from working place. Her future dream is to be involved in garment work.

\section{Case Study: 5}

Arif Rahman, 16 years of age, lived in Bastuhara arese of of Tongi. Both of his parent her dead. He has two brothers and two sisters but having no regular contract with them. He becomes a homeless for natural disaster and social neglect. He has no educational facilities and earns her livelihood by tea/jalmuri etc. Per day his income is 100-150 taka. He has limited medical, sports facilities. Sometimes he goes to cinema hall for enjoying movie. He faces pity assault during selling product. Public attitude towards him is moderate. He is badly addicted towards drugs and took part in picketing during hartal for money. He faces harassment from police frequently. He wants to be a businessman in his future life.

\section{Summary}

The nature of homeless adolescent's lifestyle increased their probability to be victim. At the same time in the same society, several adolescent become a social victim or unexpected offender while some others are not because of treating in a different manner. Their interactive skills and behaviors place them at great risk for serious victimization 
when on their own. This research examined that, maximum $(37.5 \%)$ homeless adolescents residential place is slum area, many of their parents has dead (47.5\%), monthly income of homeless adolescents parents lies between 30006000 taka (67.5\%), most of homeless adolescents have no regular contract with their family $(70 \%)$ which creates poor familial and social bond, highest number of them do not get the facility of education (86.7\%). Besides, Homeless adolescents are deprived of basic needs as majority of them have no opportunity of recreation (59.2\%), of medical facilities (95.8\%). For earning livelihood, the majority of the homeless adolescents are involved in the employment $(88.3 \%)$ as day laborers $(68.3 \%)$, maximum the homeless adolescents are involved in risky job (92.5\%) and are working 4-8 hours per day (75\%) who get less than 100 taka as salary $(79.2 \%)$ but majority of them are not getting salary in due time $(95 \%)$. Also most of the homeless adolescents are victim by physical torture $(72.5 \%)$ and many of them victim of sexual harassment $(24.2 \%)$.

Furthermore, as per the objectives of the study intend to find out the attitude of public and legal authority, it shows the homeless adolescents are seriously being victimized by public and legal authority, majority of them get very bad behavior from public (69.2\%) and police (65.8\%). In this way, homeless adolescents become hazardous social victim. Because of homelessness and after being victimized, their risks of involving with various types of pity offences are increased and frequently committing anti social behavior. Moreover, this study shows that, maximum (80\%) homeless adolescents committed pity offences for social neglect (57.5\%), get involved in drug abuse (74.2\%) and committed pity offences $(80 \%)$, and finally involved with various criminal gangs $(85.8 \%)$. The case study analysis indicates that the livelihood of homeless adolescents are seriously vulnerable, they are struggling in every sphere of life. Besides, they are unenthusiastically treated in society and face the re-victimization. But still some of them are dreaming that their future will be improved than their present condition. There are available law regarding adolescent but government does not take appropriate step for improvement of the victimized condition of the homeless adolescent as well as they are not taken for proper rehabilitation from deviant behavior.

\section{CONCLUSION}

Homeless adolescents of today faces a variety of social, cultural, political, economical, biological and natural forces which not only affect the physical growth but also hamper their social, moral and intellectual development. Apart from the bare and common human needs such as parental care, food, shelter, clothing, health, education, and recreation, enough safety and security, getting involved in the employment for earning their livelihood, some sociopsychological needs are also required to be consciously fulfilled for growth and development of homeless adolescents. Lack of balance in all this respect encourage itself in form of various problem situation like child labor, begging, mental retardation, truancy and school dropout, delinquency, gangsters, vocational maladjustment defiance of authority.

Most of the homeless adolescents are victimized for social neglect. To recover these homeless adolescents from this situation it is required adapting new intervention to deal with the victimized group, their rehabilitation, and other necessary step. All the basic needs of homeless adolescents are needed to be ensured by the government. Education should play a central role with awareness-raising and advocacy. It is necessary to take step for proper medical and entertainment facilities so that the mental maturity of homeless adolescents can develop properly. Law enforcement agencies can take more responsibility to give them enough legal support in preventing their anti social behavior. Carefully planned interventions are important, based on informed decisions by key actors in society including government, bilateral and multilateral agencies, international organizations and NGOs, civil society and community organizations.

\section{REFERENCES}

Bard M. \& Sangrey D. (1986). The Crime Victim's Book, 2nd edition, New York: Bruner/Mazel Publishers.

Baron S.W. \& Hartnagel, T.F. (1998). Street Youth and Criminal Violence, Journal of Research in Crime and Delinquency, Vol. 35 (2)

Bender, Thompson H., \& Williams. (2010). Homeless Youth: Characteristics, Contributing Factors, and Service Options, Washington, DC: The United States conference of Mayors

Brennan, T., Blanchard F., Huizinga D., \& Elliott D. (1975). The incidence and nature of runaway behavior, Indiana University: Springer Publishing Company.

Cauce and Colleagues .(1999). Childhood Victimization and Crime Victimization Research and Evaluation, Tampa: University of South Florida Press.

Elliot, Huizinga \& Menard. (1989). Homeless youth and their exposure to and involvement in violence while living on the streets, California: Behavioral Research Institute.

Endres C. (2010) Homeless adolescents' victimization, McKinney-Vento homeless program, Bristol: The Policy Press.

Finkelhor D. \& Asdigian N. L. (1996). Risk factors for youth victimization: Beyond a lifestyle/routine activities theory approach, Boston: New England Journal of Public Policy: Vol. 8. 
Hagan, J. \& McCarthy, B. (1997). Mean streets: Youth crime and Homelessness. United Kingdom: Cambridge University Press. http:/ / scholarworks.umb.edu/nejpp/vol8/iss1/20

http:/ / www.ncbi.nlm.nih.gov/pubmed/9168383

http://www.researchgate.net/publication/248921226_Homeless_Youth_Characteristics_Contributing_Factors_and_Service_Options http:/ / www.Unicef.Org/Bangladesh/Children_4865.Htm

https://www.ncjrs.gov/pdffiles1/ojjdp/195737.pdf

International Labour Organization (ILO). Baseline Survey on Child Domestic Labour in Bangladesh, Multiple Indicator Cluster Survey 2009, Report on National Child Labour Survey, 2009-2010.

Jennifer N. Shaffer \& R. Barry Ruback, (1986). Violent Victimization as a Risk Factor for Violent Offending Among Juveniles, Washington, DC: Office of Juvenile Justice and Delinquency Prevention.

Kipke \& Colleagues .(1997). Street youth, their peer group affiliation: differences according to residential status, subsistence patterns, and use of services, Canada, National press academy.

Kothari C.R. (1990). Research Methodology, Second Edition, Wishwa Prokashan.

National Coalition for the Homeless (NCH) .(2009). How many people experience homelessness, Washington, DC: National Coalition for the Homeless.

Rivera paul, Beverl, Widom \& Cathy Spatz .(1990). Childhood Victimization and Violent Offending, Journal of Violence and Victims, Vol. 5.

Rokea, Rahman .(2009). A Vulnerability of homeless adolescents in tea garden, Sylhet: UN child fund Human Development Research center.

Save the Children. (2009). A handbook for International Save the children Alliance member, $2^{\text {nd }}$ edition, Denmark: Save the children.

Silbert M., \& Pines, A. (1981). Sexual child abuse as an antecedent to prostitution, Journal of Child Abuse and Neglect, Vol .5

Tyler \& Melander .(1998). Child Abuse, Street Victimization, and Substance Use among Homeless Young Adults, New Brunswick: Transaction Publishers.

Tyler, Hagewen \& Melander, (1997). Abusive family backgrounds and later victimization among runaway and homeless adolescents, Journal of Research on Adolescence, 25 (3)

Tyler, Kimberly A., Beal, \& Morgan R. (2010). The High-Risk Environment of Homeless Young Adults: Consequences for Physical and Sexual Victimization, Journal of interpersonal violence, Sage publication.

Wenzel, Holloway Golinelli, Bowman \& Tucker .(2005). Social Networks of Homeless Youth in Emerging Adulthood, Journal of Interpersonal Violence, 16 (8).

Whitbeck, L. B. \& Simons R. L .(1990). Life on the streets: The victimization of runaway and homeless adolescents, Journal of Youth and Society, Vol. 22(1).

Whitbeck, Tyler, \& Paradise .(2005). Deviant Behavior and Victimization among Homeless and Runaway Adolescents, Lexington, MA: Lexington Books. 